\title{
A Proposal to Incorporate Job Resilience and Flexible Work Arrangement to Socially Responsible Human Resources Management Case Study: Algerian Organizations
}

\author{
Messen Kerroumia ${ }^{1}$ \& Sawssan Saadaoui ${ }^{2}$ \\ ${ }^{1}$ Faculty of Management, Saida University, Algeria \\ ${ }^{2}$ Faculty of Management, Sfax University, Tunisia \\ Correspondence: Salam II, Saida, Faculty of Management, Saida University, Algeria. E-mail: \\ k.messen@yahoo.fr \\ Received: April 7, 2020 \\ Accepted: May 16, 2020 \\ Online Published: June 5, 2020 \\ doi:10.5539/ijbm.v15n7p57 \\ URL: https://doi.org/10.5539/ijbm.v15n7p57
}

\begin{abstract}
The fierce competition imposed on organizations to invest in human resource development, these organizations realized that having a market share or manufacturing high quality products will not be achieved only by technology or capital, but with skills and effectiveness of its human resources, which is considered as the thinker, the creator, the innovator and the developer.

In this study, we address the issue of modern practices of human resources management as employee resilience, flexible work and time, social responsibility, which has received a lesser conceptual and empirical attention specifically, from managers perspective.

More importantly, we tried to draw attention to the importance of resilience and flexibility in work, and how they can be combined with other practices of social responsibility, such as transparency and fairness among employee.

We tried to evaluate to what extent the human resources departments under study committed toward social responsibility, then to bridge this concept to job resilience and flexible work arrangement.

This study was applied at four manufacturing Algerian organizations, on a sample of 43 managers, heads of departments and supervisors. By conducting a questionnaire that contained questions covering four axes including demographic questions, data process was done by SPSS version 23; we confirmed the existence of a strong positive relationship and a statistical significance between the three concepts, and between these latter and the personal characteristics of respondents such as Age and experience. We conclude that what is needed in today Algerian organizations the supportive leadership as well as socially responsible management.
\end{abstract}

Keywords: social responsibility, human resources management, resilience, flexible work arrangement, Algerian organizations

\section{Introduction}

In 1980s, a new concept took place in the domain of management which is Human resource management (HRM). In this line, many researchers have tried to define this new concept. The first definition that we can accord to the human resource management is about the manner used by responsible in organization to manage their employees. (Legall, 1996) in this way, view the HMR as « a corporate function that aims to achieve effective and sustained over time between employees and jobs in terms of numbers and qualifications match. It aims, further optimizing skills to the business strategy». In the same vein, (Godonou, 2009) indicated that HRM constitutes a considerable source to identify procedures and activities used in involving human resources and improving individual's performance and organization's efficiency.

In this paper, we investigate job resilience and flexible work arrangements according to a new concept which is socially responsible HRM (SR-HRM). For resilience, authors argued that resilience represent not only the capacity of employees to improve the organization's performance, but also, to get well and handle in the moment of change (Carmeli \& Markman, 2011).

As for flexible work arrangements (FWAs), it was defined, according to (Rau \& Hyland, 2002) as the activities 
that help in the achievement of work. It constitutes, in other hand, all the strategies, formal or informal, which allow people to achieve what they need in work.

In this study, our first investigation demonstrate that the human potential is crucial for the right functioning of a company and that particular attention should be paid to human resources because they value all other forms of company resources. In this way, companies should maintain their performance by ameliorating the employees' possession of necessary features and providing the appropriate behavioral index and reinforcements in order to guide and motivate desired behaviors.

In this vein, our paper tries to investigate the following questions:

1) Do respondents know about human resources management challenges?

2) To what extent the respondents in our case study adapt the modern practices of resources management?

3) How organizations can bridge resilience, FWA, and socially responsible HRM?

To answer these questions, we opt in this study to concentrate on Algerian economic business organization especially manufacturing ones operating in the West of Algeria. In this way, the objective of this paper is to explore resilience and flexible work arrangements in the context of socially responsible HRM. We seek to analyze certain hypotheses:

H1: In our case study Human resources management is socially responsible

H2: Human resources management in this study applies Flexible work arrangement

H3: Human resources management applies practices that develop resilience

H4: There is no significant statistical relationship between socially responsible management and between flexible work arrangement and resilience practices

H5.1: There is no significant statistical relationship between commitment toward social responsibility and respondents' age, gender, educational level, experience and training.

H5.2: There is no significant statistical relationship between use of flexible work arrangement and respondents' age, gender, educational level, experience and training.

H5.3: There is no significant statistical relationship between practices that develop resilience and respondents' age, gender, educational level, experience and training.

For more clarification we used the following framework:



Figure 1. Study framework

The paper presents a literature review explaining our research context, methodology to examine the study different hypotheses, and then a discussion and conclusion take place at the end of this study.

\section{Literature Review}

\subsection{Definition of Human Resources Management}

In general, human resource management denotes the manner to employ and manage people in organizations. It constitutes, according to some authors, a replacement to the term «personal management». In this way, there 
have been active efforts to define the concept of human resource management (HRM). At first, a definition was presented by (Storey, 1995), which establishes that HRM is a unique approach of managing employment that try to pursue a competitive advantage. Besides, according to (Boxall \& Purcell, 2000), HRM comprise all things related to the managing of relationships existing between employees in the organization. In addition, according to these authors, human resource management symbolize a number of practices used in handling employees at the various levels of organization in order to attain organization's objectives.

Recently, as for (Armstrong, 2016) HRM correspond to an important strategy which focus on developing employee working in organizations. In the same way, (Boxall \& Purcell, 2016) argue that human resource management represent a process by which organization try to fulfill their needs by ameliorating the human performance and building the workforce.

To conclude, regarding on its importance, Taylor and (Armstrong, 2015) expect the objectives of HRM. They may: 1) Support the organization in achieving its objectives by developing and implementing HR strategies that are integrated with business strategy; 2) Contribute to the development of a high-performance culture ;3) Ensure that the organization has the talented, skilled and engaged people it needs ; 4) Create a positive employment relationship between management and employees and a climate of mutual trust ; and 5) Encourage the application of an ethical approach to people management.

\subsection{Socially Responsible HMR}

In recent years, many researches have interested to the relationship that exists between Corporate Social Responsibility (CSR) and HRM such as researches presented by (Aust et al., 2018), (Nie et al., 2018). As a result of these researches a new concept which is «Socially Responsible HRM (SR-HRM)» Appeared to existence. This concept focuses on those procedures and activities which have a major role in gratifying the needs of employee at work and at their life. In this line, according to (Voegtlin et al., 2016), most researches concerning SR-HRM have tried to demonstrate the importance of SR-HRM in developing organizational performance and employee behavior. So that, some studies seeks to identify those policies and practices using in identifying a definition to the SR-HMR (Jamaliet al., 2015). In this way, (Diaz et al., 2018) considered a variety of policies such as staffing, training, performance evaluation...etc. In other words, (Barrick et al., 2015) policies of SR-HMR are those actions that make value for employees, boosting their commitment to the organization and providing to realize a competitive advantage. So that, developing SR-HMR represent a major tool not only to sustain the employee's expectations but also to improve and maintain the success of organizations for long-term.

\subsection{Flexible Work Arrangements (FWAs) and Employee Resilience: A Challenge for HRM}

\subsubsection{Flexible Work Arrangements}

Authors have mentioned many definitions for FWAs. It was defined, according to (Rau \& Hyland, 2002) as «the arrangements that allowing work to be accomplished outside of the traditional temporal and/or spatial boundaries of the standard workday». Flexible work arrangements are seen, also, as all strategies, formal or informal, which allow people to achieve what they need in work (Maxwell et al., 2006). In addition, Flexible work arrangements have been known like a way which allows employees to be satisfied not only in their work but also in their personal lives (Shockley \& Allen 2007). It is the arrangements that «enabling employees to have some choice to determine how long, when, or where they are engaged in work for various time periods» (Kossek \& Michel, 2011).

This systematic way used to decrease absenteeism, increase morale and productivity. Without affecting organizational performance, the concept was introduced for the convenience of the worker. It allows employees to be free in using their time, flexible in work patterns.

\subsubsection{Employee Resilience}

The origin of the concept of resilience takes place in the theories of positive psychology and positive organizational behavior (Avey et al., 2009). It is conceptualized in the literature as « a capability that helps individuals survive and find meaning under adverse and turbulent circumstances, such as those experienced during the wave of liberalization » (Bustinza et al., 2016). According to (Williams et al., 2016) resilience constitutes the aptitude to maintain performance in a difficult situation and to get well in a case of change. In the same way, (Luthans, 2002) resilience is defined as the ability to recover from «adversity, conflict, failure, or even positive events, progress, and increased responsibility». Finally, (Kossek et al., 2016) note that resilience is the capacity to familiarize with difficulty.

\subsubsection{Human Resources Practices (HRPs) and Employee Resilience}


Earlier research indicates that HRPs could influence resilience (Bardoel et al., 2014; Robertson et al., 2015). In this sense, different practices of human resource have an impact on the performance of organization and the satisfaction of employee in work, according to (Tims et al., 2013). Furthermore, (Xing et al., 2016) proved that a suitable human resource practices can make a comprehensible analyze of behavioral method, fit to the development of employee, which arrange practical organizational outcomes. Moreover, some researches (Coutu 2002), (Avey et al., 2008) and (Bustinza et al., 2016) proved that resilience created from human resources practices or policies should develop on employee that capacity to obtain skills and to prosper in instable situation.

\section{Methodology and Results}

After we presented the most important in the management literature using scientific references and researches; we resorted to the descriptive analytical method, through a field survey aimed at describing the reality of applying modern roles and practices of human resource management, from managers perspectives;

Due to the large study population and the limited financial capabilities of the researchers, the study was limited to the most known four public organizations active in western Algeria, they are classified as medium and large organizations according to the number of their employees that ranges from 100 to 500 employee; all are depended on organized and specialized human resource departments; and they produce food, building materials and other industrial supplies.

\subsection{Study Sample}

The study was conducted on managers, supervisors and heads of human resources departments in the organizations under study. 60 questionnaires were distributed on the purposive sample, 43 of them were valid for study, and they constituted $67 \%$ of the total number of distributed questionnaires, which is acceptable for scientific research purposes.

Table 1. Sample characteristics

\begin{tabular}{lll}
\hline Variable & Value Label & $\mathrm{N}$ \\
\hline Gender & Male & 31 \\
& Female & 12 \\
Age & Less than 28 & 8 \\
& 28 to 36 & 13 \\
& 37 to 45 & 12 \\
Education & More than 45 & 10 \\
& Undergraduate & 4 \\
Experience & Graduate & 32 \\
& Post graduat & 7 \\
\multirow{3}{*}{ Training } & less than 5 & 7 \\
& 5 to 10 & 20 \\
Job & More than 10 & 16 \\
& Less than 3 & 21 \\
& 3 to 6 & 17 \\
& More than 6 & 5 \\
\hline
\end{tabular}

It is clear from the table above that most of the respondents $72 \%$ are males, it is also noted that $76 \%$ are younger than 46 years old, those with a Bachelor's and Postgraduate degree account for 90\%. And that $83 \%$ of respondents have worked in these organizations for more than four years.

About $50 \%$ of the sample respondents have at most two training courses, While 11 percent get more than six trainings, the remaining proportion received from three to six trainings.

The sample is divided according to jobs in three categories as shown in the above table; Note that $78 \%$ of respondents work in the Human Resources Departments or have a direct relationship with these departments. 


\subsection{Study Tool}

The study relied on the questionnaire as a tool to collect data. Then we submitted it to the specialists for guidance, review and audit, after we ensured clarity of paragraphs and their relevance to the research objectives. The questionnaire was distributed to 18 individuals for a preliminary examination (pilot study).

The questionnaire was carefully designed to include all questions and hypotheses of the study;

$\diamond \quad$ The first part included personal data such as gender, age, educational qualification and professional data such as experience and the number of training program.

$\diamond$ As for the second part, it included three axes that address the modern practices of human resources management in the organization, in total 15 questions, each section contains five questions.

Responses to the study questionnaire were selected according to Likert scale, ranges from: 1=strongly disagree, to $5=$ strongly agree.

On this basis, the Mean values will be classified as follows: from 1 to $2.49=$ Disagree/2.5 to $3.49=$ neither agree nor disagree $/ 3.5$ to $5=$ Agree .

\subsection{Reliability Statistics}

To verify the Reliability of the questionnaire, Cronbach's Alpha coefficient was calculated and it was found that its value amounted to $(0.711)$ for all items of the questionnaire, which is considered acceptable.

Table 2. Questionnaire Reliability

\begin{tabular}{ll}
\hline Cronbach's Alpha & N of Items \\
\hline, 711 & 15 \\
\hline
\end{tabular}

\subsection{Hypothesis Tests}

H1: Human resources management in our case study applies Flexible work arrangement

Table 3. Findings concerning flexible work arrangement application

\begin{tabular}{|c|c|c|c|c|}
\hline \multicolumn{2}{|c|}{ Items } & \multirow{2}{*}{$\begin{array}{l}\text { Mean } \\
3,14\end{array}$} & \multirow{2}{*}{$\begin{array}{l}\text { Std. } \\
\text { Deviation } \\
, 743\end{array}$} & \multirow[b]{2}{*}{$\begin{array}{l}\text { neither agree } \\
\text { nor disagree }\end{array}$} \\
\hline 1. & Helping employees to balance work commitments and family life & & & \\
\hline 2. & Reduction of staff hours & 3,49 & ,631 & Agree \\
\hline & $\begin{array}{l}\text { Absorbing fluctuations in demand (products or services) by expanding or } \\
\text { ing the size of the workforce. }\end{array}$ & 4,09 &, 718 & Agree \\
\hline 4. & Avoiding layoffs and there by the loss of valuable human capital through (FWA) & 3,95 &, 722 & \multirow{2}{*}{$\begin{array}{l}\text { Agree } \\
\text { neither agree } \\
\text { nor disagree }\end{array}$} \\
\hline 5. & Enabling employees to gain control over their time and place of work & 3,26 &, 621 & \\
\hline $\mathrm{FW}$ & & 3,59 &, 510 & Agree \\
\hline
\end{tabular}

In order to identify the extent of application of Flexible Work Arrangements in the organizations under study, Items were analyzed in terms of mean values and standard deviation.

The statistical results in the table above indicate that organizations avoid layoffs by applying FWA $(4,09)$, they Absorb fluctuations in products or services demand by enlarging or decreasing the workforce size $(3,95)$. These can be interpreted as a policy of government, because in our sample these organizations failed to consider employees' commitments of balance between work and family. Moreover, failed to enable employees to gain control over their work patterns (time and place).

$\mathrm{H} 2$ : Human resources management in our case study applies practices that develop resilience 
Table 4. Findings concerning resilience practices

\begin{tabular}{lllll}
\hline Items & Mean & Std. Deviation & \\
\hline $6 . \quad$ Social supports at work & 3,35 &, 529 & neither agree nor disagree \\
7. & Employee assistance, and development programs such as resilience training & 2,58 &, 587 & Disagree \\
$8 . \quad$ Reward systems & 3,56 &, 666 & Agree \\
$9 . \quad$ Risk and crisis management systems & 2,88 &, 625 & neither agree nor disagree \\
$10 . \quad$ Encouraging diversity of ideas and people & 3,28 &, 630 & neither agree nor disagree \\
Resilience & 3,13 &, 434 & neither agree nor disagree \\
\hline
\end{tabular}

From the table results we notice that in all statements the mean values obtained are lower than the proposed mean (3.41), except the third statement. Also that, dispersion of responses ranges from 0.529 to 0.666 which means that respondents were unanimous in their responses. Here we can say that human resources management in our case study does not apply practices that develop resilience

H3: Human resources management in our case study is socially responsible

Table 5. Findings concerning commitment to social responsibility

\begin{tabular}{|c|c|c|c|}
\hline Items & Mean & Std. Deviation & \\
\hline 11. Integration of disadvantaged groups of society into the workforce & 3,12 & 697 & neither agree nor disagree \\
\hline 12. Justice, transparency & 3,86 & ,710 & Agree \\
\hline 13. Recruit employees with social responsibility values and attitudes. & 3,19 & ,664 & neither agree nor disagree \\
\hline $\begin{array}{l}\text { 14. Practices that help develop social responsibility skills, knowled } \\
\text { competences among employees such as establishment of trainin } \\
\text { development programs }\end{array}$ & ad 3,81 &, 588 & Agree \\
\hline 15. Occupational health and safety systems & 3,84 & ,615 & Agree \\
\hline SR /HRM & 3,56 & ,475 & Agree \\
\hline
\end{tabular}

The table above showed that respondents support commitment of social responsibility in human resources management. In three cases the first Justice, transparency of recruitment $(3,86)$, the second occupational health and safety systems $(3,84)$, the third Training and development practices established to help employees develop social responsibility skills, knowledge and competences(3,81), while these organizations missed the integration of disadvantaged groups of society into the workforce and missed hiring employees with social responsibility values and attitudes, these two cases are issues that legislations do not stress.

The standard deviation determined the value of dispersion between the values of the mean, it ranges from 0,588 to 0,710 .

H4: There is no significant statistical relationship between practicing social responsibility and practicing flexible work arrangement and resilience.

Table 6. Correlations

\begin{tabular}{|c|c|c|c|c|}
\hline & & Resilience & SRHRM & FWA \\
\hline \multirow[t]{3}{*}{ Resilience } & Pearson Correlation & 1 &, $593^{* *}$ & ,667 \\
\hline & Sig. (2-tailed) & &, 000 & 000 \\
\hline & $\mathrm{N}$ & 43 & 43 & 43 \\
\hline \multirow[t]{3}{*}{ SRHRM } & Pearson Correlation &, $593^{* *}$ & 1 &, $679^{* *}$ \\
\hline & Sig. (2-tailed) & ,000 & &, 000 \\
\hline & $\mathrm{N}$ & 43 & 43 & 43 \\
\hline \multirow[t]{3}{*}{ FWA } & Pearson Correlation &, $667^{* *}$ &, $679^{* *}$ & 1 \\
\hline & Sig. (2-tailed) &, 000 &, 000 & \\
\hline & $\mathrm{N}$ & 43 & 43 & 43 \\
\hline
\end{tabular}

**. Correlation is significant at the 0.01 level (2-tailed).

After we confirmed that the sample follows the normal distribution, we calculate the correlation of Pearson to 
ensure internal consistency, and that there is a positive relationship and a statistical significance between the variables.

\subsection{Regression}

Table 7. Model summary ${ }^{\mathrm{b}}$

\begin{tabular}{lllll}
\hline Model & $\mathrm{R}$ & R Square & Adjusted R Square & $\begin{array}{l}\text { Std. Error of the } \\
\text { Estimate }\end{array}$ \\
\hline 1 &, $704^{\mathrm{a}}$ &, 496 &, 471 &, 345 \\
\hline
\end{tabular}

a. Predictors: (Constant), Resilience, FWA.

b. Dependent Variable: SRHRM.

From the table 7 results, Independent variables explain only 49 percent of social responsibility

Table 8. ANOVA $^{\mathrm{a}}$

\begin{tabular}{lllllll}
\hline Model & & Sum of Squares & Df & Mean Square & F & Sig. \\
\hline 1 & Regression & 4,694 & 2 & 2,347 & 19,696 &, $000^{\mathrm{b}}$ \\
& Residual & 4,767 & 40 &, 119 & & \\
& Total & 9,460 & 42 & & & \\
\hline
\end{tabular}

a. Dependent Variable: SRHRM.

b. Predictors: (Constant), FWA, Resilience.

Table 8 Explains (F) value is 19,696 with a significance equal to 0,000 which is less than $5 \%$; Thus the regression is significant and there is relationship between the independent variable and dependent variables

Table 9. Coefficients ${ }^{\mathrm{a}}$

\begin{tabular}{|c|c|c|c|c|c|c|c|c|c|}
\hline \multicolumn{2}{|c|}{ Model } & \multicolumn{2}{|c|}{ Unstandardized Coefficients } & \multirow{2}{*}{$\begin{array}{l}\text { Standardized } \\
\text { Coefficients } \\
\text { Beta }\end{array}$} & \multirow[t]{2}{*}{$\mathrm{t}$} & \multirow[t]{2}{*}{ Sig. } & \multicolumn{3}{|c|}{ Correlations } \\
\hline & & $\mathrm{B}$ & Std. Error & & & & Zero-order & Partial & Part \\
\hline \multirow[t]{3}{*}{1} & (Constant) & ,995 & ,419 & & 2,373 & ,023 & & & \\
\hline & FWA & ,476 &, 140 &, 511 & 3,390 &, 002 & 679 & ,472 & ,380 \\
\hline & Resilience & ,276 &, 165 & ,252 & 1,673 &, 102 &, 593 & ,256 & ,188 \\
\hline
\end{tabular}

a. Dependent Variable: SRHRM.

Through the table 9 we confirmed that there is a significant statistical relationship between FWA and Socially responsible human resources management where sig $=0,02$ and it is less than $5 \%$, while there is no significant relationship gather Socially responsible human resources management and resilience. In deed organizations in our sample do not practice resilience.

To test the other hypotheses, ANOVA analysis was used.

1) There is no significant statistical relationship between commitment toward social responsibility and respondents' age, gender, educational level, experience and training. 
Table 10. ANOVA

\begin{tabular}{|c|c|c|c|c|c|c|}
\hline & & Sum of Squares & df & Mean Square & $\mathrm{F}$ & Sig. \\
\hline \multirow[t]{3}{*}{ Gender } & Between Groups & 1,568 & 9 &, 174 & 812 & ,609 \\
\hline & Within Groups & 7,083 & 33 &, 215 & & \\
\hline & Total & 8,651 & 42 & & & \\
\hline \multirow[t]{3}{*}{ Age } & Between Groups & 9,396 & 9 & 1,044 & ,926 &, 516 \\
\hline & Within Groups & 37,208 & 33 & 1,128 & & \\
\hline & Total & 46,605 & 42 & & & \\
\hline \multirow[t]{3}{*}{ Education } & Between Groups & 1,841 & 9 & ,205 &, 754 &, 658 \\
\hline & Within Groups & 8,950 & 33 & ,271 & & \\
\hline & Total & 10,791 & 42 & & & \\
\hline \multirow[t]{3}{*}{ Experience } & Between Groups & 3,816 & 9 &, 424 &, 809 & ,611 \\
\hline & Within Groups & 17,300 & 33 &, 524 & & \\
\hline & Total & 21,116 & 42 & & & \\
\hline \multirow[t]{3}{*}{ Training } & Between Groups & 4,613 & 9 &, 513 & 1,096 & ,392 \\
\hline & Within Groups & 15,433 & 33 & ,468 & & \\
\hline & Total & 20,047 & 42 & & & \\
\hline
\end{tabular}

As the table above indicates, we accept the null hypothesis because the level of significance exceeded five percent in all variables (from 0.392 to 0.658 ) so, there is no significant statistical relationship, which means that the commitment to social responsibility in our sample is not due to the personal characteristics of the respondents, but rather to the policy of organizations under study.

2) There is no significant statistical relationship between use of flexible work arrangement and respondents' age, gender, educational level, experience and training.

Table 11. ANOVA

\begin{tabular}{|c|c|c|c|c|c|c|}
\hline & & Sum of Squares & Df & Mean Square & $\mathrm{F}$ & Sig. \\
\hline \multirow[t]{3}{*}{ Gender } & Between Groups & 1,187 & 8 &, 148 & ,676 &, 709 \\
\hline & Within Groups & 7,464 & 34 & ,220 & & \\
\hline & Total & 8,651 & 42 & & & \\
\hline \multirow[t]{3}{*}{ Age } & Between Groups & 7,724 & 8 & ,965 &, 844 &, 571 \\
\hline & Within Groups & 38,881 & 34 & 1,144 & & \\
\hline & Total & 46,605 & 42 & & & \\
\hline \multirow[t]{3}{*}{ Education } & Between Groups & 1,767 & 8 &, 221 & ,832 & ,581 \\
\hline & Within Groups & 9,024 & 34 & ,265 & & \\
\hline & Total & 10,791 & 42 & & & \\
\hline \multirow[t]{3}{*}{ Experience } & Between Groups & 4,854 & 8 & ,607 & 1,269 & ,004 \\
\hline & Within Groups & 16,262 & 34 &, 478 & & ,292 \\
\hline & Total & 21,116 & 42 & & & \\
\hline \multirow[t]{3}{*}{ Training } & Between Groups & 5,618 & 8 &, 702 & 1,655 &, 146 \\
\hline & Within Groups & 14,429 & 34 &, 424 & & \\
\hline & Total & 20,047 & 42 & & & \\
\hline
\end{tabular}

From the table above, we accept the null hypothesis. Thus, there is no significant statistical relationship between usage of flexible work arrangement and respondents' age, gender, educational level and training, as the first hypothesis results show that the personal characteristics of the respondents have no effect on the policies used in these organizations concerning flexible work arrangement, except one characteristic "the experience" where we record a significance equal to 0,004 .

3) There is no significant statistical relationship between practices that develop resilience and respondents' age, gender, educational level, experience and training. 
Table12. ANOVA

\begin{tabular}{|c|c|c|c|c|c|c|}
\hline & & Sum of Squares & Df & Mean Square & $\mathrm{F}$ & Sig. \\
\hline \multirow[t]{2}{*}{ Gender } & Between Groups & 1,662 & 8 &, 208 & 1,011 & 446 \\
\hline & Within Groups & 6,989 & 34 & ,206 & & \\
\hline \multirow[t]{2}{*}{ Age } & Between Groups & 19,449 & 8 & 2,431 & 3,044 & 011 \\
\hline & Within Groups & 27,156 & 34 & ,799 & & \\
\hline \multirow[t]{3}{*}{ Education } & Between Groups & 2,468 & 8 & ,309 & 1,261 & ,296 \\
\hline & Within Groups & 8,322 & 34 &, 245 & & \\
\hline & Total & 10,791 & 42 & & & \\
\hline \multirow[t]{2}{*}{ Experience } & Between Groups & 8,294 & 8 & 1,037 & 2,749 & ,019 \\
\hline & Within Groups & 12,822 & 34 & 377 & & \\
\hline Training & Total & 20,047 & 42 & & & \\
\hline
\end{tabular}

From the table above, we accept the null hypothesis. Thus, there is no significant statistical relationship between practices that develop resilience and respondents' gender and educational level. As the results show that other personal characteristics of the respondents have an effect on the policies used in these organizations concerning resilience: Age, Experience and training.

\section{Discussion}

The global economic development, and the large size of organizations, and then the large size of employment and the various problems that result from it creating the need for specialized management that has evolved With the development of theories and administrative schools.

Modern human resource management must play four roles to be contemporary and effective, in addition to the Strategic management where it participates in implementing the organization's strategy in an effective way; it plays a crucial role in moving the organization safely and smoothly to change as a result of intense competition (change management). Also it prepares the organization's infrastructure including policies, procedures, rules and regulations written, well prepared and available to staff on the organization's website; furthermore in the sense of knowing and meeting employee needs, it encourages creators to implement their creativity related to developing work systems and procedures.

Although respondents were aware of nowadays HRM challenges, unfortunately the departments in the organizations under study are adopting a traditional approach to meet these challenges.

Generally the results indicated a weak application of modern practices:

- These departments do not apply practices that develop resilience;

- They practice Flexible work arrangement especially in what concerns economic government policy since they are public sector organizations (avoiding layoffs as example);

- personal characteristics of the respondents have no effect on the policies used in these organizations concerning flexible work arrangement, except one "the experience"

- They are committed to social responsibility in human resources management especially in some cases such as Justice and transparency of recruitment, while they missed the integration of disadvantaged groups of society into the workforce also they missed hiring employees with social responsibility values and attitudes; probably because these two cases are issues that legislations do not stress.

On the other side, our statistical study confirmed (Stavrou, 2005) results who established that organizations can avoid layoffs by applying FWA, they Absorb fluctuations in products or services demand by enlarging or decreasing the workforce size. Our results support (Timset al, 2013) findings, Training and Experience have an effect on the practices approved in these organizations.

Furthermore, Correlation results ensure internal consistency, a strong positive relationship and a statistical significance between resilience practices, FW arrangement and the socially responsible Human Resources Management. 
Some recommendation to meet the challenges:

- $\quad$ Permanent support from top level management to apply the modern practices.

- We encourage managers to participate, exchange knowledge and communicate with experts outside the organization.

- More attention should be paid to employees' personality and background because this will help in determining resilience practices and FW arrangements.

- Retain employees who have substantial experience and knowledge as they represent the competitive weight of the company.

- Finally, what is needed in today Algerian organizations the supportive leadership as well as socially responsible management.

We invite those interested in research in this field to access a broader set of relevant literatures;It is crucial for future research to seek to develop our idea of the ways in which HR practitioners can effectively implement these practices and to determine the view of this combination it from employee perspective, And also the application in private organizations.

\section{References}

Armstrong, M. (2016). Armstrong's Handbook of Strategic Human Resource Management. London, Kogan Page.

Armstrong, M., \& Taylor, S. (2015). Armstrong's Handbook of Human Resource Management Practice. London, Kogan Page.

Aust, I., Muller-Camen, M., \& Poutsma, E. (2018). Sustainable HRM: A comparative and international perspective. In Brewster, C., Farndale, E., \& Mayrhofer, W., (Eds.), Handbook of Research in Comparative Human Resource Management (2nd ed., pp. 358-369). Cheltenham, UK: Edward Elgar Publishing. https://doi.org/10.4337/9781784711139.00026

Avey, J. B., Luthans, F., \& Jensen, S. M. (2009). Psychological capital: A positive resource for combating employee stress and turnover. Human resource management, 48(5), 677-693. https://doi.org/10.1002/hrm.20294

Avey, J. B., Wernsing, T. S., \& Luthans, F. (2008). Can positive employees help positive organizational change? Impact of psychological capital and emotions on relevant attitudes and behaviors. The Journal of Applied Behavioural Science, 44(1), 48-70. https://doi.org/10.1177/0021886307311470

Bardoel, E. A., Pettit, T. M., De Cieri, H., \& McMillan, L. (2014). Employee resilience: anemerging challenge for HRM. Asia Pacific Journal of Human Resources, 52(3), 279-297. https://doi.org/10.1111/1744-7941.12033

Barrick, M., Thurgood, G., Smith, T., \& Courtright, S. (2015), Collective organizational engagement: Linking motivational antecedents, strategic implementation, and firm performance. Acad. Manag. J., 58, 111-135. https://doi.org/10.5465/amj.2013.0227

Boxall, P., \& Purcell, J. (2000). Strategic human resource management: where have we come from and where should we be going? International Journal of Management Reviews, 2(2), 183-203. https://doi.org/10.1111/1468-2370.00037

Boxall, P., \& Purcell, J. (2016). Strategy and Human Resource Management. London, Palgrave Macmillan. https://doi.org/10.1007/978-1-137-40765-8

Bustinza, O. F., Vendrell-Herrero, F., Perez-Arostegui, M., \& Parry, G. (2016). Technological capabilities, resilience capabilities and organizational effectiveness. The International Journal of Human Resource Management, 1-23. https://doi.org/10.1080/09585192.2016.1216878

Carmeli, A., \&Markman, G. D. (2011). Capture, Governance, and Resilience: Strategy Implications from the History of Rome. Strategic Management Journal, 32(3), 322-341. https://doi.org/10.1002/smj.880

Coutu, D. L. (2002). How resilience works. Harvard Business Review, 80(5), 46-56.

Diaz-Carrion, R., López-Fernández, M., \& Romero-Fernandez, P. M. (2018) Developing a sustainable HRM system from a contextual perspective. Corp. Soc. Responsib. Environ. Manag.. https://doi.org/10.1002/csr.1528

Godonou, C. K. (2009). De la function personnelle traditionnelle à la function resources humaines: une etude 
empirique auprès des enterprises bénénoises. Communication, Congrès AGRH, Dakar.

Jamali, D., El Dirani, A. M., \& Harwood, I. A. (2015). Exploring human resource management roles in corporate social responsibility: the CSR-HRM co-creation model. Business Ethics, A European Review, 24, 125-143. https://doi.org/10.1111/beer.12085

Kossek, E. E., \& Michel, J. (2011) Flexible workscheduling. In S. Zedeck (Ed.), Handbook of Industrial-Organisational Psychology. Washington, DC. https://doi.org/10.1037/12169-017

Kossek, E. E., \& Perrigino, M. B. (2016). Resilience: A reviewusing a grounded integrated occupational approach. The Academy of Management Annals, 10(1), 729-797. https://doi.org/10.5465/19416520.2016.1159878

Legall, J. M. (1996). La Gestion des ressources humaines. PUF, collection Que sais-je.

Luthans, F. (2002a). The need for and meaning of positive organizational behaviour. Journal of Organisational Behaviour, 23(6), 695-706. https://doi.org/10.1002/job.165

Maxwell, G., Rankine, L., Bell, S., \& MacVicar, A. (2007). The incidence and impact of FWAs in smaller businesses. Employee Relations, 29(2), 138-161. https://doi.org/10.1108/01425450710719987

Nie, D., Lämsä, A. M., \& Pucetaite, R. (2018), Effects of responsible human resource management practices on female employees' turnover intentions. Bus. EthicsEur. Rev. 27, 29-41. https://doi.org/10.1111/beer.12165

Rau, B. L., \& Hyland, M. M. (2002). Role conflict and flexible work arrangements: The effects on applicant attraction. Personnel Psychology, 55(1), 111-136. https://doi.org/10.1111/j.1744-6570.2002.tb00105.x

Robertson, I. T., Cooper, C. L., Sarkar, M., \& Curran, T. (2015). Resilience training in the work place from 2003 to 2014: A systematic review. Journal of Occupational and Organisational Psychology, 88(3), 533-562. https://doi.org/10.1111/joop.12120

Shockley, K. M., \& Allen, T. D. (2007). When flexibility helps: Another look at the availability of FWAs and work-family conflict. Journal of Vocational Behavior, 71(3), 479-493. https://doi.org/10.1016/j.jvb.2007.08.006

Storey, I. (1995). Human Resource Management: A Critical Text. London, Routledge.

Tims, M., \& Bakker, A. B. et al. (2013). The impact of job crafting on job demands, job resources, and well-being. Journal of Occupational Health Psychology, 18(2), 230. https://doi.org/10.1037/a0032141

Voegtlin, C., \& Greenwood, M. (2016). CSR and HRM: A Review and Conceptual Analysis. Hum. Resour. Manag. Rev., 26, 181-197. https://doi.org/10.1016/j.hrmr.2015.12.003

Williams, T., \& Shepherd, D. (2016). Building Resilience or Providing Sustenance: Different Paths of Emergent Ventures in the Aftermath of the Haiti Earth quake. Academy of Management Journal, 59(6), 2069-2102. https://doi.org/10.5465/amj.2015.0682

Xing, Y., \& Liu, Y. et al. (2016). Intercultural influences on managing African employees of Chinese firms in Africa: Chinese managers' HRM practices. International Business Review, 25(1), 28-41. https://doi.org/10.1016/j.ibusrev.2014.05.003

\section{Copyrights}

Copyright for this article is retained by the author(s), with first publication rights granted to the journal.

This is an open-access article distributed under the terms and conditions of the Creative Commons Attribution license (http://creativecommons.org/licenses/by/4.0/). 